\title{
Bioactivity of diatomaceous earth to Sitophilus zeamais (Coleoptera: Curculionidae) in different application conditions
}

\author{
Adalberto H. Sousa' ${ }^{1}$ Lêda R. A. Faroni ${ }^{2}$, Gilberto S. Andrade ${ }^{3}$, \\ Romenique S. Freitas ${ }^{2} \&$ Marco A. G. Pimentel ${ }^{4}$
}

\begin{abstract}
The objective of this study was to evaluate the insecticidal activity of diatomaceous earth (DE) at different ambient temperatures on adult Sitophilus zeamais and progeny, using different doses and exposure periods. The experiments were performed in Petri dishes containing $40 \mathrm{~g}$ of the whole corn kernel, treated with $\mathrm{DE}$ at doses of $0,0.25,0.5$ and $1.0 \mathrm{~kg} \mathrm{Mg}^{-1}$. Each dish was infested with $25 \mathrm{~S}$. zeamais adults and kept at climatic chambers under temperatures of $20,25,30,35$ and $40^{\circ} \mathrm{C}$. The insect mortality was recorded after six and 15 days from the beginning of the bioassays. The grains evaluated at 15 days were separated from insects and kept in the dishes for another 75 days under the same temperature conditions. After this period the effect of ambient temperature and of diatomaceous earth doses on the emergence of $S$. zeamais in the $F_{1}$ generation was evaluated. It was found that the mortality of $S$. zeamais increased with the higher dose and temperature during the exposure period of six and 15 days. The number of insects emerged reduced with increasing temperature in these two exposure periods. The increase of temperature and exposure period favored the efficacy of DE in lower doses for control of $S$. zeamais.
\end{abstract}

Key words: corn weevil, inert dusts, storage, insect control

\section{Bioatividade da terra de diatomácea para Sitophilus zeamais (Coleoptera: Curculionidae) em diferentes condições de aplicação}

\section{RESUMO}

O objetivo deste trabalho foi avaliar a atividade inseticida da terra de diatomácea (TD) em diferentes temperaturas ambiente sobre adultos de Sitophilus zeamais e sua progênie, utilizando-se diferentes doses e períodos de exposição. Os experimentos foram realizados em placas de Petri contendo $40 \mathrm{~g}$ de grãos inteiros de milho, tratados com TD nas doses de $0 ; 0,25 ; 0,5$ e 1,0 $\mathrm{kg} \mathrm{Mg}^{-1}$. Cada placa foi infestada com 25 adultos de $S$. zeamais e mantida em câmaras climáticas nas temperaturas de $20,25,30,35$ e $40{ }^{\circ} \mathrm{C}$. A mortalidade dos insetos foi contabilizada após seis e 15 dias do início dos bioensaios. Os grãos avaliados aos 15 dias foram separados dos insetos e mantidos nas placas por mais 75 dias sob as mesmas condições de temperatura. Após este período avaliou-se o efeito da temperatura ambiente e das doses da TD sobre a emergência de $S$. zeamais na geração $F_{1}$. Verificou-se que a mortalidade de $S$. zeamais aumentou com o incremento da dose e da temperatura nos períodos de exposição de seis e 15 dias; já o número de insetos emergidos reduziu com o aumento da temperatura nesses dois períodos de exposição. $\mathrm{O}$ aumento da temperatura e do período de exposição favoreceu a eficácia da TD em menores doses, para controle de S. zeamais.

Palavras-chave: gorgulho-do-milho, pós-inertes, armazenamento, controle de insetos

\footnotetext{
1 UFAC, Campus Rio Branco, BR 364, km 04, Distrito Industrial, CEP 69.920-000, Rio Branco, AC. E-mail: adalberto@ufac.br

2 UFV, Campus Viçosa, Av. P.H. Rolfs, s/n, CEP 36.570-000, Viçosa, MG. Email: Ifaroni@ufv.br, romeniquefreitas@hotmail.com

${ }^{3}$ Universidade Federal de Rondônia, Campus Rolim de Moura, Av. Norte Sul, 7.300, Morada Nova, CEP 76.940-000, Rolim de Moura, RO. E-mail: gilbertoandrade1@yahoo.com.br

${ }^{4}$ Embrapa Milho e Sorgo, MG 424, km 45, CEP 35.701-970, Sete Lagoas, MG. E-mail: marco.pimentel@embrapa.br
} 


\section{INTRODUCTION}

Insect pests of stored products are responsible for considerable economic losses in the storage sector. The Sitophilus zeamais Mots. (Coleoptera: Curculionidae) is a major corn pest and its by products are found in virtually all storage and processing facilities of Brazil (Aguiar et al., 2010; Conceição et al., 2012). This insect is controlled by pyrethroid and organophosphate insecticides (Guedes et al., 2008) and phosphine fumigant (Sousa et al., 2009). However, in view of the high levels of resistance to these insecticides, the incorporation of new forms of control to handle pest insects in the storage sector is important (Freitas et al., 2011).

The integration of non-chemical control methods can mitigate problems related to the presence of residues in food and resistance of pest by overuse of these products (Kavallieratos et al., 2009; Mwololo et al., 2012). Handling of the temperature of the grains and the post-inert employment, such as diatomaceous earth, are examples of non-chemical promising methods for the integrated handling of insect pests of stored products (Kavallieratos et al., 2007; Wakil et al., 2010). Diatomaceous earth is originated from sediment of carapaces of diatomaceous algae and when in contact with insects cause the removal of the layer of wax from their cuticle, bringing about their death by dissection (Rojht et al., 2010).

Diatomaceous earth effectively controls most species of insect pests of stored grain. This product acts on larvae and adult insects, adhering to their body as they move on the surface or inside the treated grain mass (Kavallieratos et al., 2007; Rojht et al., 2010; Shams et al., 2011). In addition, it presents advantages such as low toxicity for mammals and to the environment, leaves no harmful residues in the treated product, is effective against species of insects resistant to insecticides, is persistent and stable at high and low temperatures, and does not affect the quality of the product (Subramanyam \& Roesli, 2000).

The diatomaceous earth source, dose and exposure period, moisture content and temperature of the grain mass are factors that influence the mortality of insects (Fields \& Korunic, 2000; Athanassiou et al., 2007; Rojht et al., 2010). To this end, it was noted in previous studies that the temperature is the main barrier to the adaptation in the mass of grains and reproduction of insects (Fields \& Korunic, 2000; Vayias \& Stephou, 2009). Moreover, this factor causes uneven distribution of insects in the grain mass due to larger dispersion at high temperatures and movement reduction at low temperatures. The abrasive effect of diatomaceous earth can increase or decrease with the increase of the ambient temperature, causing variation in toxicity (Chanbang et al., 2007; Vayias et al., 2009). However, studies are required on the toxicity of the diatomaceous earth on different doses and exposure period in association with the ambient temperature for insect pests from stored products.

Thus, the objective of this study was to evaluate the insecticidal activity of diatomaceous earth at different ambient temperatures on adult $S$. zeamais and progeny, using different doses and exposure periods.

\section{Material And Methods}

Bioassays were performed in the Laboratory of Integrated Pest Handling of Grains at the Federal University of Viçosa.
The influence of different ambient temperatures $(20,25,30$, 35 and $40{ }^{\circ} \mathrm{C}$ ) on the effectiveness of diatomaceous earth at different doses and the exposure period, in the control of $S$. zeamais was investigated.

The insects of $S$. zeamais were obtained from cultures maintained in the Laboratory of Integration of Pest of Grains, in the Universidade Federal de Viçosa, which were reared in $1.5 \mathrm{~L}$ glass flasks under constant conditions of temperature (27 $\left.\pm 2{ }^{\circ} \mathrm{C}\right)$ and relative humidity $(70 \pm 5 \%)$ and $24 \mathrm{~h}$ scotophase. Whole maize grains with a moisture content of $13 \%$ wet basis (wb), were used as a food substrate. The grains were previously expurgated with phosphine and maintained under refrigeration $\left(-18{ }^{\circ} \mathrm{C}\right)$ to prevent re-infestation.

The Diatomaceous earth used was the national brand ( $\mathrm{B}$ KeepDry, with at least $86 \%$ of amorphous silicon dioxide $\left(\mathrm{SiO}_{2}\right)$ particles of about $15 \mu \mathrm{m}$ and apparent density of $200 \mathrm{~g} \mathrm{~L}^{-1}$; light beige color, insoluble in water and of dry powder appearance.

To evaluate the toxicity of diatomaceous earth on S. zeamais, experiments were performed in Petri dishes $(140 \times 10 \mathrm{~mm})$ containing $40 \mathrm{~g}$ of whole maize grain, with moisture content of $13 \%$ w.b., treated with diatomaceous earth at the doses of 0.25 , 0.5 and $1.0 \mathrm{~kg} \mathrm{Mg}^{-1}$. Each Petri dish was infested with 25 adult unsexed $S$. zeamais, with age varying from one to three weeks. Then, they were kept in a BOD chambers at temperatures of $20,25,30,35$ and $40 \pm 2{ }^{\circ} \mathrm{C}$ under constant relative humidity conditions $(70 \pm 5 \%)$ and scotophase of $24 \mathrm{~h}$. The control treatment was conducted under the same conditions, using, however, whole maize grains untreated with diatomaceous earth. Insect mortality was recorded after six and 15 days from the beginning of the bioassays.

Before accounting for mortality, insects were sieved to separate the grains. Then, the grains were observed in light camera to verify the presence of insects inside. Adult mortality of $S$. zeamais was evaluated at the different exposure times, temperatures and doses of diatomaceous earth. The grains evaluated at 15 days were kept in Petri dishes for another 75 days under the same conditions of temperature, relative humidity and scotophase in which bioassays were conducted. After this period the effect of ambient temperature and of diatomaceous earth doses on the emergence of S. zeamais in the $\mathrm{F}_{1}$ generation was evaluated.

The design used was a completely randomized in a $4 \times 5$ factorial, with three replications. The used factorial $(4 \times 5)$ was compound for four doses of diatomaceous earth $(0.0,0.25,0.5$ and $\left.1.0 \mathrm{~kg} \mathrm{Mg}^{-1}\right)$ and five ambient temperatures $(20,25,30$, 35 and $40{ }^{\circ} \mathrm{C}$ ). Mortality data were subjected to covariance analysis, using SAS software (PROC GLM, SAS Institute, 2002). For significant interactions, unfolding of the data was performed. From the values obtained regression analysis were performed as a result of temperature, through the SigmaPlot software, version 7.0 (SPSS, 2001).

\section{RESUlts AND Discussion}

The mortality of $S$. zeamais varied significantly between the doses of diatomaceous earth and ambient temperatures, both for the exposure period of six days $\left(\mathrm{F}_{3 ; 40}=121.88 ; \mathrm{P}<0.01\right.$ and $\left.\mathrm{F}_{4 ; 40}=160.46 ; \mathrm{P}<0.01\right)$ and for the period of fifteen days $\left(\mathrm{F}_{3 ; 40}=\right.$ 
122.76; $\mathrm{P}<0.01$ and $\left.\mathrm{F}_{4: 40}=62.46 ; \mathrm{P}<0.01\right)$. The interaction doses versus temperatures, also, was significant at $\operatorname{six}\left(\mathrm{F}_{12 ; 40}=16.77\right.$; $\mathrm{P}<0.01)$ and fifteen days $\left(\mathrm{F}_{12 ; 40}=24.96 ; \mathrm{P}<0.01\right)$ of exposure.

It was found that the toxicity of diatomaceous earth increased with temperature elevation at both doses and exposure periods of diatomaceous earth (Figure 1, Table 1). An exception was only seen for the dose of $1.0 \mathrm{~kg} \mathrm{Mg}^{-1}$ in the exposure period of fifteen days, where the mortality of insects was next to or equal to $100 \%$ in the five temperatures studied. The number of dead insects in the treatments with doses of $0.25,0.5$ and $1.0 \mathrm{~kg} \mathrm{Mg}^{-1}$ at temperatures of $20,25,30$ and $35^{\circ} \mathrm{C}$ was substantially greater than in the control at the end of the period of six day exposure. For the exposure period of 15 days the mortality in these doses was compared to control at temperatures of 20,25 and $30^{\circ} \mathrm{C}$. At other temperatures there was no variation in mortality between treatments with diatomaceous earth and control.

The number of adult insects obtained in the progeny of $S$. zeamais varied significantly between the doses of diatomaceous earth $\left(\mathrm{F}_{3: 40}=171.57 ; \mathrm{P}<0.01\right)$ and ambient temperatures $\left(\mathrm{F}_{4: 40}=89.79 ; \mathrm{P}<0.01\right)$. The interaction between these two variables was also significant $\left(\mathrm{F}_{12 ; 40}=39.08 ; \mathrm{P}<0.01\right)$. The number of insects emerged, at the end of the exposure period of 75 days, reduced with the increase in the dose of diatomaceous earth and in the ambient temperature (Figure 2, Table 1). The reduction of the number of insects as a result of the increase in temperature tended to be more expressive with increasing dose of the insecticide, except for the dose of $1.0 \mathrm{~kg}$ $\mathrm{Mg}^{-1}$. In this treatment, the number of insects emerged was null or very near to zero at all temperatures. The number of insects emerged from grains treated with diatomaceous earth at doses of $0.25,0.5$ and $1.0 \mathrm{~kg} \mathrm{Mg}^{-1}$ at temperatures of 20,25 and 30 ${ }^{\circ} \mathrm{C}$ was substantially less than the grain in the control. At the temperatures of 35 and $40^{\circ} \mathrm{C}$ there was no variation among the doses of diatomaceous earth and control.

The effectiveness of diatomaceous earth to $S$. zeamais increased with higher doses of the insecticide and with the temperature of the environment. This effect shows that the mortality of insects is dependent on the conditions in which the grains are exposed to the action of diatomaceous earth. It is

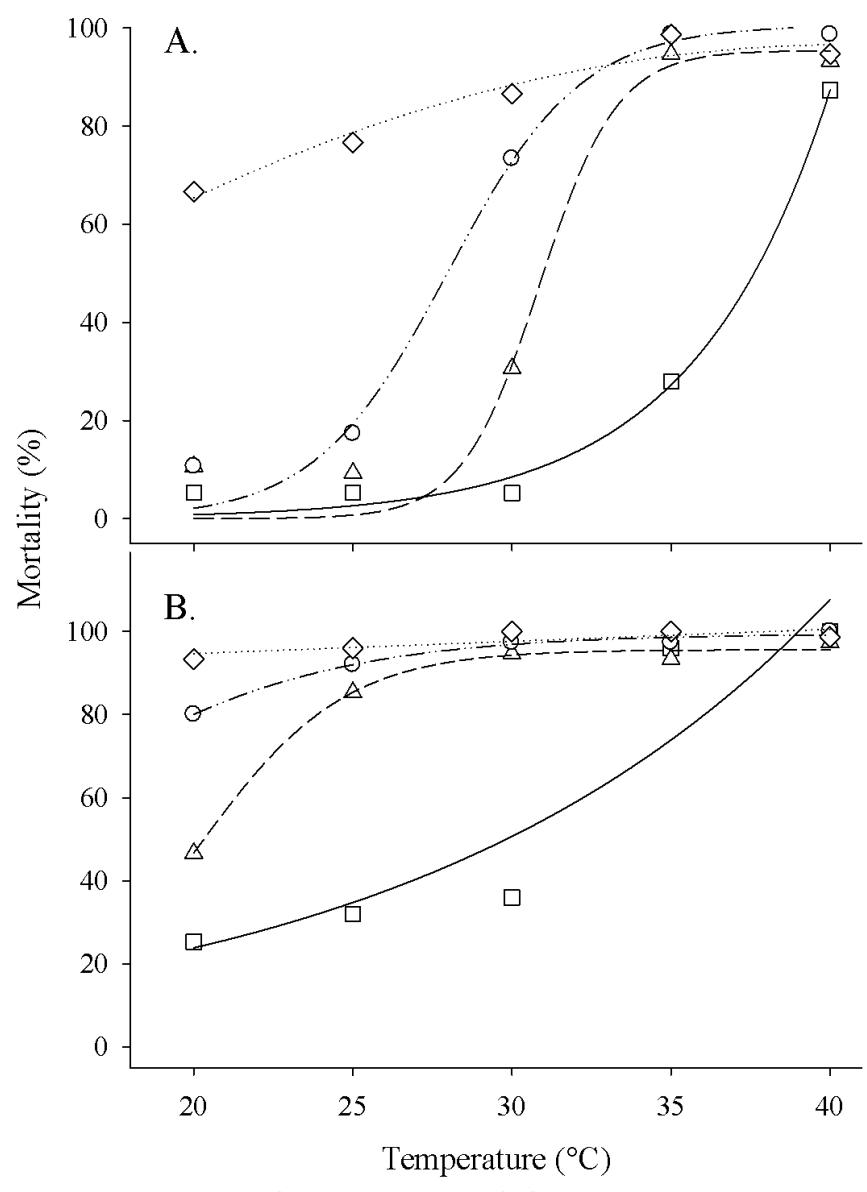

Figure 1. Mortality (\%) of Sitophilus zeamais in maize grains treated with diatomaceous earth at doses of 0.25 $(\Delta), 0.5(0)$ and $1.0(\diamond) \mathrm{kg} \mathrm{Mg}^{-1}$ and control $(\square)$, under different temperatures, during 6 (A) and 15 (B) days

known that the efficacy of the insecticides is usually influenced by a number of factors, among which are the dose of product, the ambient temperature or substrate, and the exposure period (Fields \& Korunic, 2000; Athanassiou et al., 2007). The increase in temperature favors the effectiveness of this product for insect pests of stored products. High temperatures stimulate

Table 1. Summary of the regression analysis for mortality and progeny (adult insects) of Sitophilus zeamais treated with diatomaceous earth at the doses of $0.25,0.5$ and $1.0 \mathrm{~kg} \mathrm{Mg}^{-1}$ and control, during 6 and 15 days for the mortality bioassays and 15 days for the bioassays of progeny evaluation

\begin{tabular}{|c|c|c|c|c|c|c|c|c|c|}
\hline \multirow{2}{*}{ Variable } & \multirow{2}{*}{$\begin{array}{c}\text { Dose } \\
\left(\mathrm{kg} \mathrm{Mg}^{-1}\right)\end{array}$} & \multirow{2}{*}{ Model* } & \multicolumn{3}{|c|}{ Estimated parameters $( \pm \mathrm{EPM})^{* *}$} & \multirow{2}{*}{$\begin{array}{l}\text { G.L. } \\
\text { error }\end{array}$} & \multirow{2}{*}{$\mathbf{F}$} & \multirow{2}{*}{$P$} & \multirow{2}{*}{$\mathbf{R}^{2}$} \\
\hline & & & a & b & C & & & & \\
\hline \multirow{2}{*}{6 days } & 0.50 & $y=a /(1+\exp (-(x-b) / c))$ & $100.55 \pm 5.32$ & $27.98 \pm 0.62$ & $2.08 \pm 0.46$ & 2 & 89.65 & 0.01 & 0.99 \\
\hline & Control & $y=a \exp (b x)$ & $0.01 \pm 0.01$ & $0.23 \pm 0.02$ & - & 3 & 388.01 & $<0.01$ & 0.99 \\
\hline \multirow{2}{*}{15 days } & 1.00 & $y=97,6$ & - & - & - & - & - & - & - \\
\hline & 0.50 & $y=a /(1+\exp (-(x-b) / c))$ & $99.49 \pm 1.04$ & $13.55 \pm 1.20$ & $4.56 \pm 0.86$ & 2 & 102.43 & $<0.01$ & 0.99 \\
\hline \multirow{4}{*}{ Progeny } & 1.00 & $y=1,4$ & - & - & - & - & - & - & - \\
\hline & 0.50 & $y=a \exp \left(-0,5((x-b) / c)^{2}\right)$ & $13.73 \pm 1.17$ & $25.27 \pm 0.44$ & $2.91 \pm 0.28$ & 2 & 47.74 & $<0.01$ & 0.89 \\
\hline & 0.25 & $y=a \exp \left(-0,5((x-b) / c)^{2}\right)$ & $28.95 \pm 6.17$ & $27.85 \pm 0.31$ & $2.85 \pm 0.74$ & 2 & 42.28 & $<0.01$ & 0.88 \\
\hline & Control & $y=a \exp \left(-0,5((x-b) / c)^{2}\right)$ & $108.42 \pm 5.53$ & $26.15 \pm 0.22$ & $3.63 \pm 0.21$ & 2 & 136.22 & $<0.01$ & 0.96 \\
\hline
\end{tabular}

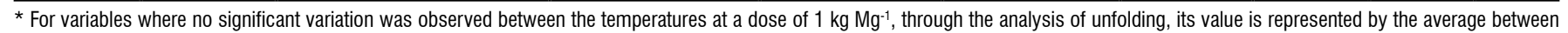
the temperatures

${ }^{\star *}$ All estimated parameters were significant at $\mathrm{P}<0.05$ by the t-Student's test 


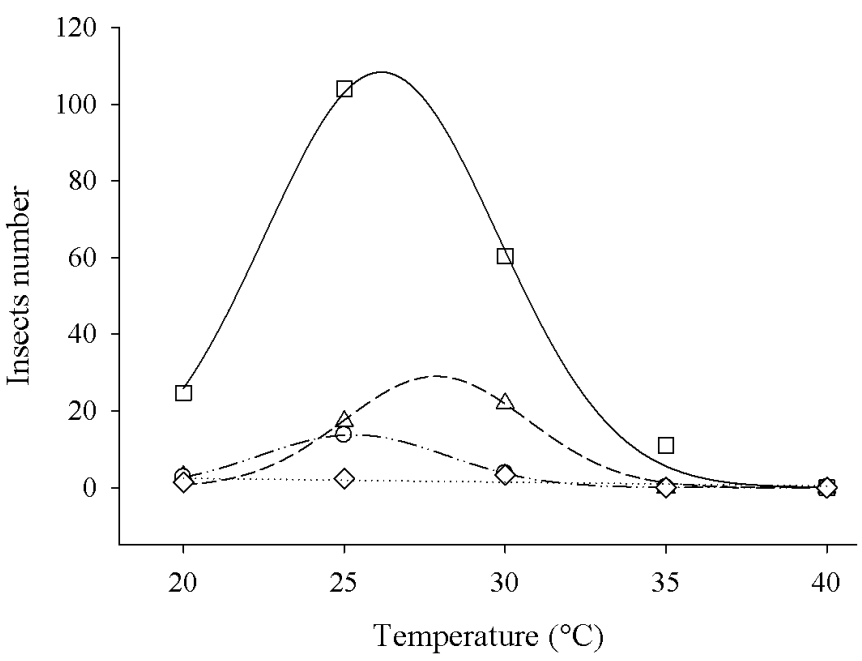

Figure 2. Adult progeny of Sitophilus zeamais in maize grains treated with diatomaceous earth at doses of 0.25 $(\Delta), 0.5(\circ)$ and $1.0(\diamond) \mathrm{kg} \mathrm{Mg}^{-1}$ and control ( $\left.\square\right)$, under different temperatures, during 75 days

the movement of insects within the grain mass, allowing them greater contact with the diatomaceous earth (Chanbang et al., 2007; Vayias et al., 2009). In addition to that, the upper threshold of temperature for each specimen can cause changes in the respiratory rate of the insects (Käfer et al., 2012), causing higher loss of water through spiracles and, consequently, the dissection and death (Vayias \& Stephou, 2009).

Although the toxicity of the diatomaceous earth has increased with high temperature, the mortality was more pronounced from $30^{\circ} \mathrm{C}$ in an exposure period of six days than at $25^{\circ} \mathrm{C}$ in an exposure period of 15 days. In agreement with observations for mortality of adults, the number of emerged insects in progeny reduced in proportion with increasing temperature, reaching zero at all doses at temperatures of 35 and $40{ }^{\circ} \mathrm{C}$. These results are due to the fact that higher temperatures may reduce the rate of oviposition and limit the survival of insects, reducing the number of individuals in the progeny (Vardeman et al., 2006). In addition, the high mortality rates observed for temperatures of 35 and 40 ${ }^{\circ} \mathrm{C}$ in the exposure period of 15 days may have influenced the number of insects in progeny, since it reduced the number of individuals able to reproduce in almost $100 \%$.

The results presented in this study indicate that the combination of lower doses with high temperatures and longer periods of exposure can effectively control insect pests of stored products. These results indicate that in tropical regions one can achieve greater efficiency of diatomaceous earth using lower doses, which does not favor a possible evolution of the resistance of populations for this product. Additionally, it is worth noting that one of the major factors limiting the use of diatomaceous earth is the amount of powder left in the grains, which can be reduced when using lower doses (Vayias \& Stephou, 2009). Thus, the doses of 0.25 and $0.5 \mathrm{~kg} \mathrm{Mg}^{-1}$ can be recommended to control insect pests of stored products in places with a minimum temperature of the environment of 30 ${ }^{\circ} \mathrm{C}$, under the exposure period equal to or above 6 days. These same dosages can be recommended for environments with a minimum temperature of $25{ }^{\circ} \mathrm{C}$ under exposure period equal to or above 15 days.

\section{Conclusions}

1. The increase in temperature potentiate the toxicity of diatomaceous earth to $S$. zeamais at different doses and exposure times.

2. With the increase in ambient temperatures there is an increase in adult mortality and reduction in insect emergence.

3. Lower doses are more effective at high temperatures and longer exposure times for the $S$. zeamais control.

\section{ACKNOWLEDGEMENT}

The "Coordination of Improvement of Higher Education Personnel (CAPES)", "Foundation for Research Support of Minas Gerais (FAPEMIG)" and "National Council for Scientific and Technological Development (CNPq)".

\section{Literature Cited}

Aguiar, R. W. S.; Faroni, L. R. A.; Guedes, R. N. C.; Sousa, A. H.; Rozado, A. F. Toxicidade da combinação de dióxido de carbono e fosfina sob diferentes temperaturas para Tribolium castaneum. Revista Brasileira de Engenharia Agrícola e Ambiental, v.14, p.881-886, 2010.

Athanassiou, C. G.; Kavallieratos, N. G.; Peteinatos, G. G.; Petrou, S. E.; Boukouvala, M. C.; Tomanović, Z. Influence of temperature and humidity on insecticidal effect of three diatomaceous arth formulations against aarger grain borer (Coleoptera: Bostrychidae). Journal of Economic Entomology, v.100, p.599-603, 2007.

Chanbang, Y.; Arthur, F. H.; Wilde, G. E.; Throne, J. E. Efficacy of diatomaceous earth to control Rhyzopertha dominica (F.) (Coleoptera: Bostrichidae) in rough rice: Impacts of temperature and relative humidity. Crop Protection, v.26, p.923-929, 2007.

Conceição, P. M.; Faroni, L. R. A.; Sousa, A. H.; Pimentel, M. A. G.; Freitas, R. S. Diatomaceous earth effects on weevils with different susceptibility standard to phosphine. Revista Brasileira de Engenharia Agrícola e Ambiental, v.16, p.303307, 2012.

Fields, P.; Korunic, Z. The effect of grain moisture content and temperature on the efficacy of diatomaceous earths from different geographical locations against stored-product beetles. Journal of Stored Products Research, v.36, p.1-13, 2000.

Freitas, R. S.; Faroni, L. R .A.; Sousa, A. H.; Cecon, P. R.; Carvalho, M. S. Quality of beans stored under hermetic conditions. Engenharia Agrícola, v.31, p.1136-1149, 2011.

Guedes, R. N. C.; Campbell, J. F.; Arthur, F. H.; Opit, G. P.; Zhu, K. Y.; Throne, J. E. Acute lethal and behavioral sublethal responses of two stored product psocids to surface insecticides. Pest Management Science, v.64, p.1314-1322, 2008.

Käfer, H.; Kovac, H.; Stabentheiner, A. Resting metabolism and critical thermal maxima of vespine wasps (Vespula sp.). Journal of Insect Physiology, v.58, p.679-689, 2012. 
Kavallieratos, N. G.; Athanassiou, C. G.; Vayias, B. J.; Maistrou, S. Influence of temperature on susceptibility of Tribolium confusum (Coleoptera: Tenebrionidae) populations to three modified diatomaceous earth formulations. Florida Entomologist, v.90, p.616-625, 2007.

Kavallieratos, N. G.; Athanassiou, C. G.; Vayias, B. J.; Mihail, S. B.; Tomanović, Z. Insecticidal efficacy of abamectin against three stored-product insect pests: influence of dose rate, temperature, commodity and, exposure interval. Journal of Economic Entomology, v.102, p.1352-1359, 2009.

Mwololo, J. K.; Mugo, S. N.; Tefera, T.; Okori, P.; Munyiri, S. W.; Semagn, K.; Otim, M.; Beyene, Y. Resistance of tropical maize genotypes to the larger grain borer. Journal of Pest Science, v.85, p.267-275, 2012.

Rojht, H.; Horvat, A.; Athanassiou, C. G.; Vayias, B. J.; Tomanović, Z.; Trdan, S. Impact of geochemical composition of diatomaceous earth on its insecticidal activity against adults of Sitophilus oryzae (L.) (Coleoptera: Curculionidae). Journal of Pest Science, v.83, p.429-436, 2010.

SAS Institute. SASSTAT User's Guide, Version 8.0. Cary: SAS Institute, 2002.

Shams, G; Safaralizadeh, M. H; Imani, S. Insecticidal effect of diatomaceous earth against Callosobruchus maculatus (F.) (Coleoptera: Bruchidae) and Sitophilus granarius (L.) (Coleoptera: Curculionidae) under laboratory conditions. African Journal of Agricultural Research, v.6, p.5464-5468, 2011.
Sousa, A. H.; Faroni, L. R. A.; Pimentel, M. A. G.; Guedes, R. N. C. Developmental and population growth rates of phosphine-resistant and -susceptible populations of storedproduct insect pests. Journal of Stored Products Research, v.45, p.241-246, 2009.

SPSS. Sigma Plot user's guide, Version 7.0 (revised edition). Chicago: SPSS, 2001.

Subramanyam, B., Roseli, R. Inert dusts. In: Subramanyam, B., Hagstrum, D. W. (ed.) Alternatives to Pesticides in Stored-product IPM. Boston: Kluwer Academic Publishers, 2000. p.312-380.

Vardeman, E. A.; Arthur, F. H.; Nechols, J. R.; Campbell, J. F. Effect of temperature, exposure interval, and depth of diatomaceous earth treatment on distribution, mortality, and progeny production of lesser grain borer (Coleoptera : Bostrichidae) in stored wheat. Journal of Economic Entomology, v.99, p.1017-1024, 2006.

Vayias, B. J.; Athanassiou, C. G.; Buchelos, C. T. Effectiveness of spinosad combined with diatomaceous earth against different European strains of Tribolium confusum du Val (Coleoptera: Tenebrionidae): Influence of commodity and temperature. Journal of Stored Products Research, v.45, p.165-176, 2009.

Vayias, B. J.; Stephou, V. K. Factors affecting the insecticidal efficacy of an enhanced diatomaceous earth formulation against three stored-product insect species. Journal of Stored Products Research, v.45, p.226-231, 2009.

Wakil, W.; Ashfaq, M.; Ghazanfar, M. U.; Riasat, T. Susceptibility of stored-product insects to enhanced diatomaceous earth. Journal of Stored Products Research, v.46, p.248-249, 2010. 